\title{
Island på vej mod EU?
}

\section{Erik Boel}

\section{Det er symptomatisk, at islændinges tilslutning til euroen er langt stærkere end til EU-medlemskab}

På hovedstrøget i Reykjavik står der skrevet i asfalten: "Lysere tider er på vej med blomstermarker og lange, skønne sommertimer”. Citat Islands nationaldigter Halldor Laxness.

Uanset at Armani og andre smarte modebutikker er lukket ned på Reykjaviks hovedstrøg, fejler selvbevidstheden på vulkanøen ikke noget. Mange nye butikker er skudt op, hvor man forhandler islandske sweaters - nu gælder det identiteten og om at komme tilbage til rødderne. Island er ved at træde ud af finanskrisens slagskygge: På havnen i Reykjavik ligger det monumentale koncerthus netop færdiggjort, og det matcher operaen i Sydney. Det har 400 flere siddepladser end operaen i København.

Men denne nye beherskede optimisme betyder også, at interessen for EU-medlemskab er stærkt vigende. Interessen for EU har vist sig at bygge på kviksand i den forstand, at den var tæt forbundet med krisestemningen og kronens fald i 2008.

Det er stærkt beklageligt set fra et dansk synspunkt: Hvis Island blev medlem af EU, ville det nordiske islæt i samarbejdet blive styrket. Islandsk medlemskab vil fremme interessen for EU på både Færøerne og i Norge, hvor det utvivlsomt ville påvirke holdningen til EU hos kystbefolkningen op langs den norske vestkyst, hvis Island fik en tilfredsstillende ordning på fiskeriområdet.

Visionen er en genforening af Norden og større gennemslagskraft for nordisk pragmatik og fælles værdier om velfærd, bæredygtighed og ligestilling i Europa.

Island søgte om medlemskab i sommeren 2009 og har siden været inde i en forhandlingsproces. Forhandlinger der går smertefrit - fordi Island har dygtige forhandlere, og fordi det er de relativt nemme kapitler, man er startet på - selv om der har været politisk sprængstof $i$ forhandlingerne om fødevaresikkerhed og miljø. Forhandlingerne om finansielle spørgsmål, landbrug og det sværeste - fiskeriet - er udskudt.

Baggrunden for den hurtige pro- 
ces er også, at Island allerede i dag opfylder mange af EU's krav, når det gælder fx miljøet og arbejdsmarkedet. I realiteten er 10 af 33 forhandlingskapitler afsluttet pga. Islands medlemskab af EØS og Schengen, og yderligere 10 er delvist afsluttede. Det er forventningen, at ved afslutningen af 2012 vil omkring 30 kapitler været åbnede og omkring 12 lukket. Groft sagt vil Island til næste forår antagelig være halvvejs gennem forhandlingsprocessen.

Erhvervslivet og fagbevægelsen er generelt positivt indstillet til islandsk medlemskab af EU - bortset fra i fiskerierhvervet. Selv de intellektuelle, der ellers har dukket sig, er ved at komme på banen: For nylig skrev en række universitetsprofessorer et åbent brev, hvori de fastslog, at et EU-medlemskab er i Islands grundlæggende interesse ud fra et økonomisk synspunkt.

Vist er der i befolkningen tilslutning til at fortsætte forhandlingerne om EU-medlemskab. Men med en økonomi der er ved at komme på fode, siger $2 / 3$ af befolkningen nu nej tak til selve medlemskabet. Hertil kommer, at der i Island - som mange andre steder i Europa - er en tendens til at gøre EU og euroen til syndebukke for den økonomiske krise.

\section{Forfatningsændring}

Et eventuelt islandsk medlemskab af Unionen vil også forudsætte en æn- dring af landets forfatning, der ikke som den danske grundlov fra 1953 tager højde for, at landet kan tilslutte sig et så forpligtende samarbejde som det europæiske.

Allerede i dag er den islandske grundlov en hæmsko for en udvikling af landets deltagelse i EØS-samarbejdet. Der bliver folkeafstemning om en grundlovsændring - men der har ikke været politisk stemning for at gøre muligheden for suverænitetsafgivelse til en del heraf. Endelig er selve forhandlingsprocessen vanskeliggjort af, at Islands S-SF regering internt er dybt uenig om EU, og EU-medlemskab som mål er ikke en del af regeringsgrundlaget.

Det eneste rigtige europaparti Socialdemokraterne som leder den nuværende regering - bløder i meningsmålingerne. Noget tyder på, at partiet ved valget til Altinget, som seneste skal holdes til april 2013, vil skulle overlade ledelsen af regeringen til Selvstændighedspartiet, der står til en kanonsejr med 38 pct. af stemmerne i den seneste meningsmåling. Ofte bliver tilslutningen til Selvstændighedspartiet dog overvurderet i målingerne. Det skyldes, at mens Selvstændighedspartiet er enerådende på højresiden i islandsk politik, er der mange partier til venstre, og mange vælgere her er derfor mere usikre på, hvilket af partierne de vil stemme på.

Et helt centralt problem for Island på landets eventuelle vej gennem EU's nåleøje er manglen på politisk 
lederskab i EU-spørgsmålet og manglen på en proeuropæisk midte i det politiske landskab, som kan bære EU-processen igennem på islandsk side. Formentlig vil en eventuel ny borgerlig regering lade EU-forhandlingerne køre videre - men uden drive og uden begejstring.

I Selvstændighedspartiet er det kun en minoritet, der er pro-EU, og som i øvrigt ikke gør megen væsen af sig. Fremskridtspartiet (svarede oprindelig til Venstre i Danmark, men har bevæget sig mod venstrefløjen) var før sidste valg for EU, men har slået en kolbøtte og siger nu nej tak. Det hører med i billedet, at Islands præsident netop har vundet en 5. valgperiode på en populistisk anti-EU platform. Præsidentens beføjelser er begrænsede, men han vil i princippet kunne stikke en kæp i hjulet i den videre proces ved at kræve en ny folkeafstemning. Det betyder, at følgende scenario ikke kan udelukkes: Forhandlingerne afsluttes, resultatet sendes til folkeafstemning, hvor det bliver ja, parlamentet bekræfter ja'et - og derefter kaster præsidenten endnu engang forslaget til folkeafstemning; fx med henvisning til at valgdeltagelsen i den første afstemning var for lav.

\section{Icesave-sagen}

Den såkaldte Icesave-sag har også pustet til nationalismen på Island. Sagen handler om islandske bankfilialers indskyderforpligtigelser over for kontohavere i Storbritannien og Holland, som de islandske skatteydere i sidste ende kommer til at hænge på. Det er ikke småpenge, der er tale om. Det skønnes, at regningen til skatteborgerne kan komme til at ligge på hen ved $1 / 3$ af landets årlige produktion. I marts 2010 udskrev regeringen en folkeafstemning om en løsning af sagen, der resulterede i, at 93 pct. stemte nej. I et nyt oplæg til folkeafstemning som blev afholdt 9. april 2011, var der lagt op til, at den rente, islændingene skal bære, blev reduceret fra 5 til 3 pct. Men igen blev det et nej med 56,8 pct imod aftalen.

Selv om alt i dag tyder på, at de britiske og hollandske indskydere vil få tilbagebetalt deres penge, er 'Icesave' også udadtil mere end en sten i skoen. Den Internationale Valutafond, som har spillet en vigtig rolle som redningsmand under krisen, vil have et kritisk fokus på, om sagen bliver håndteret tilfredsstillende. $\mathrm{Og}$ såvel Storbritannien som Holland vil kunne forsinke Islands vej mod EUmedlemskab, hvis ikke problemerne bliver løst. EU - heriblandt Danmark - har støttet UK og Nederlandene i denne sag, hvilket har dæmpet stemningen for Unionen betydeligt på Island.

EU har anlagt sagen ved EFTAdomstolen for at få afklaret ansvarsfordelingen i den type sager. Her kan behandlingen nemt tage op til 2 år. Og så længe sagen kører, vil kapitlerne i forhandlingerne om fi- 
nans- og valutaspørgsmål ikke kunne afsluttes.

Icesave-sagen har pustet til nationalismen i Island og til en følelse af, at alle vender Island ryggen. En følelse der har ligget latent, siden amerikanerne abrupt - sådan blev det oplevet af islændingene - afviklede deres engagement på Keflavikbasen i 2006 med negative konsekvenser for islandsk indtjening og beskæftigelse. EU-modstanderne har brugt folkeafstemningerne om 'Icesave' som en generalprøve på EU-afstemningen og vil spille på, at EU i Ice-save-sagen blev oplevet som fjendtlig over for Islands interesser. Under alle omstændigheder kaster nej'erne ved Icesave-folkeafstemningerne skygger over EU-forhandlingerne.

Der er en stigende politikerlede på Island i lyset af finanskrisen. Ifølge en meningsmåling har kun 12 pct. af befolkningen tillid til politikerne - langt under den tillid andre autoriteter nyder. En række nye protestpartier er dukket op - fire ligger over spærregrænsen på 4 pct. Ved det seneste lokalvalg i Reykjavik gik borgmesterposten til en skuespiller, der kun ville afgive ét valgløfte - at bryde alle sine løfter!

\section{Islands SF}

Det spiller en rolle, at der i Altinget i sin tid kun var 33 mod 28 medlemmer, der stemte for ansøgningen. $\mathrm{Og}$ af de 33 stemte de venstre-grøn- ne (svarer til SF i Danmark) kun ja, fordi partiet er i regering med Socialdemokraterne, og statsminister Jóhanna Sigurðardóttir havde gjort det klart, at faldt forslaget, faldt regeringen også.

Det islandske SF vil gerne demonstrere, at de har bevæget sig fra protestparti til regeringsdueligt parti, men ganske som i Danmark er det en særdeles smertefuld proces.

Indtil videre er det ikke lykkedes formanden for de venstre-grønne at dreje partiet i mere pro-europæisk retning. Det er ikke fremmende for EU-processen, at mens forhandlingerne kører, bekræfter regeringspartiet gang på gang, at det er imod medlemskab.

En række karakteristika ved den islandske elite trækker også i retning af EU-skepsis: Valgreglerne betyder, at provinsen er overrepræsenteret i Altinget, dvs. fiskeriet og landbruget som er EU-skeptisk. Den islandske centraladministration har navnlig tidligere været svag, og derfor har skiftende regeringer i hvert fald indtil midten af 1990'erne støttet sig til fiskeriets og landbrugets organisationer i formuleringen af europapolitikken.

Forsvaret af konkrete økonomiske interesser har været i centrum for Islands udenrigspolitik, vægten har ligget på udviklingen af bilaterale kontrakter snarere end det multilaterale samarbejde og med et bestandigt ønske om at hævde landets suverænitet. 
Den islandske elite - politikere, forretningsfolk og bureaukrater har traditionelt haft de tætteste forbindelser til de mere skeptiske EUlande i Norden samt Storbritannien og USA. Indtil for nylig har dette også været tilfældet i forhold til uddannelse og kultur.

Selv om kontakterne til det europæiske kontinent trods alt styrkes, og flere og flere islændinge rejser til Bruxelles, er det nu engang lettere at skabe forståelse for nødvendigheden af det europæiske samarbejde på det europæiske kontinent end midt ude i Atlanterhavet.

I islandske regeringskredse lægges der heller ikke skjul på, at landets status som EU-ansøgerland forbedrer kreditværdigheden og stillingen i forhold til den Europæiske Centralbank. Det er symptomatisk, at den folkelige tilslutning til at komme med i euroen er langt stærkere end til EU-medlemskabet.

Det er også de økonomiske argumenter EU-tilhængerne fører i marken - helt som i Danmark tilbage i 1972: forbrugere og virksomheder vil få glæde af lavere varepriser og lavere rente ved medlemskab, euroen vil kunne udgøre et bolværk for Islands svage og udsatte finanssystem, og EU's fonde vil kunne hjælpe landet i forhold til egnsudvikling, landbrug og turisme. Det bør dog ikke overses, at for mange EU-tilhængere spiller de følelsesmæssige argumenter også en rolle. Tidligere statsminister Palsson fra Selvstæn- dighedspartiet peger på, at islændingene er europæere både når det gælder forståelsen af de menneskelige rettigheder og opbygningen af et moderne velfærdssamfund. Palsson mener, at Islands udfordringer i en globaliseret verden kun kan håndteres gennem deltagelsen i et tæt europæisk samarbejde - og han ser en lige linje fra Islands forankring i de euro-atlantiske strukturer i 1949 og frem til den dag Island måtte blive medlem af EU.

\section{Let spil for nej}

Et centralt problem for ja-siden er, at der ikke er megen information og debat om Islands forhold til EU. Socialdemokraterne holder lav profil af hensyn til koalitionspartneren SF. Det betyder, at nej-siden har let spil, og den har nærmest formået at skabe et billede af, at det er EU, der ansøger om, at få Island optaget.

En del EU-modstandere, som $\mathrm{fx}$ den tidligere miljøminister for de rød-grønne og nuværende formand for kunstnersammenslutningen Kolbrún Halldórsdottir, ser en risiko for, at et eventuelt EU-medlemskab vil betyde, at Unionen vil føre stormagtspolitik i Nordatlanten med betoning af økonomiske, ressourcemæssige og strategiske interesser. Oprindelig ønskede Island ikke engang at deltage i FN, og aftalen med amerikanerne om at benytte Keflavik-basen under den kolde krig var i sin tid både kontroversiel og behæf- 
tet med stærke reservationer.

Man behøver ikke hyre nogen spindoktor for at føre nej-kampagne på den baggrund; den tidligere statsminister David Oddsson gør det allerede, idet han spiller på de nationalistiske strenge, hvor det nærmest fremstilles som om, at Island kan leve af fisk og får alene: Island vil som et lille land blive mast i EUsamarbejdet, selvstændigheden vil komme under pres og Bruxelles vil blande sig i et og alt.

"300.000 islændinge får ikke en chance over for 500 mio. europæere", lyder det. Vist er Oddsson i dag er en af de mest upopulære skikkelser i Island, efter at han i de sidste 45 år indtog posten som nationalbankdirektør og efter manges opfattelse har et stort medansvar for den $\varnothing$ delæggende finanskrise. Men han spiller fortsat en vigtig politisk rolle som redaktør af den store EU-kritiske avis Morgenbladet, der har betydelig gennemslagskraft.

Mange EU-modstandere peger på, at det må række med EØS-aftalen. Omvendt peger tilhængerne på det forhold, at Island ikke får den politiske indflydelse inden for $\mathrm{E} \emptyset \mathrm{S}$ - men må tage til takke med, hvad EU-landene har forhandlet sig frem til.

Halvdelen af lovgivningen i Altinget er i dag i realiteten bestemt af EU - uden islandsk indflydelse. Men modstanderne spiller på frygten for det ukendte; forhandlingsresultatet foreligger ikke endnu, og det er ikke klart, hvilket EU det er Island i sidste ende skal tage stilling til, om man ønsker at deltage i, fordi det nye EU-samarbejde endnu kun er i støbeskeen.

En afgørende knast er selvfølgelig fiskeriet og i mindre grad landbruget. Man skal ikke mange mil uden for Reykjavik for at forstå, hvor stor en rolle fiskeriet spiller i de mange små kystbyer. I tørre tal udgør fisk 40 pct. af eksportindtægterne og knap fem pct. af den samlede beskæftigelse. Med sammenbruddet af mange banker er fiskeriets betydning i disse år stigende, og i en krisetid ser mange også fiskeriet som et økonomisk sikkerhedsnet.

For Island er det først og fremmest afgørende at bevare landets 200 sømil grænse og forbuddet mod udenlandske investeringer $\mathrm{i}$ islandsk fiskeri. Journalisten Audunn Arnarsson, der har udgivet en bog om Islands forhold til EU, fremhæver, at det problem skulle være til at løse. Han nævner, at Norge i forbindelse med optagelsesforhandlingerne først i 1990'erne fik tilsagn om særrettigheder nord for 62 . breddegrad på baggrund af, at fiskeriressourcerne heroppe var at betragte som udpræget lokale. Vist var dette tilsagn ikke af permanent karakter, men Hardarsson er overbevist om, at det kunne være blevet permanent, hvis Norge havde insisteret.

\section{Fiskeripolitikken}

Måske kan tendensen til, at EU re- 
gionaliserer sin fiskeripolitik gøre det nemmere at nå en løsning for Island. Endvidere ligger det i kortene, at forudsætningen for, at udenlandske fartøjer kan fiske mellem $12 \mathrm{og}$ 200 sømil er, at de har erfaring med fiskeriet i det pågældende område. Til fordel for, at det lykkes at finde et kompromis, taler også, at EU i realiteten ikke har én fiskeripolitik, men én for Skagerak, én for Middelhavet, én for Sortehavet osv.

I spørgsmålet om retten til udenlandske investeringer i fiskeriet kommer Island formentlig til at give sig. I dag tillader man investeringer fra udlandet op til 49 pct. af kapitalen. Men selv om Island åbner op her, vil landet formentlig kunne opstille visse restriktioner, når det gælder udenlandske investorer, eksempelvis at de skal have opholdt sig i Island i en vis årrække.

Desværre indgår det stort set ikke i debatten, at Islands fiskeripolitik på mange måder er en inspiration for EU's, som i øjeblikket er under revision: Fiskeriet får ikke statsstøtte, det er bæredygtigt, og overvågningen af fiskebestanden er langt mere effektiv end EU's. Det er fiskerierhvervet også: 1.500 islandske fiskefartøjer fanger 50 pct. flere fisk end Spaniens 11.400 fartøjer.

Modstanden mod EU-medlemskab er om muligt endnu mere benhård i landbruget end i fiskeriet. Det hænger formentlig sammen med, at landbruget ikke har de erfaringer med internationale forhand- linger, som fiskeriet trods alt har opnået. Island er selvforsynende inden for bl.a. mejeri-, ost- og oksekødsproduktion. Island vil formentlig kunne få en aftale som Finland $\mathrm{og}$ Sverige, hvor landbruget betegnes som 'arktisk', og hvor der bliver mulighed for støtte - bare Island selv betaler den. Landbruget udgør 1 $1 / 2$ pct. af BNP og repræsenterer 4.500 jobs, 10.000 jobs hvis man inkluderer tilhørende virksomheder.

For såvel fiskeri som landbrug gælder det, at erhvervenes kulturelle og menneskelige betydning rækker langt ud over deres økonomiske og beskæftigelsesmæssige rolle. I en undersøgelse, som den islandske pendant til Dansk Industri har foretaget for nylig, peger et flertal af medlemsorganisationerne på, at det er afgørende, at der findes en løsning på fiskeriets problemer - ganske uanset at de pågældende virksomheder ikke har noget med fiskerierhvervet at gøre.

Indtil videre er forhandlingerne om fiskeriet lagt på hylden, idet Frankrig og Spanien blokerer for videre forhandlinger med henvisning til, at Island nu må komme på banen med et oplæg til, hvilke ønsker Island selv har til en fremtidig ordning for det islandske fiskeri.

Den kontrol, Island har indført med kapitalbevægelserne for at sikre, at bunden ikke går ud af økonomien og af den islandske krone, vil også skulle afskaffes, førend medlemskab af EU vil kunne komme på 
tale. Kontrollen strider i virkeligheden også mod grundlaget for EØSsamarbejdet.

Også andre kontroversielle spørgsmål vil komme op under forhandlingerne så som islændingenes jagt på havfugle og hvalfangst. Netop hvalfangst kalder på stærke følelser såvel i EU som på Island. Beskæftigelsesmæssigt betyder hvalindustrien ikke meget - men i sidste ende kan et forbud mod jagt på hvaler være det spørgsmål, der vælter læsset.

\section{Et ungt land}

Kun en tåbe undervurderer EUmodstanden på Island. Her spiller de stærke følelser omkring landets uafhængighed fortsat en afgørende rolle. Island er et ungt land, der først bliver uafhængigt i 1918 i personalunion med Danmark og republik i 1944.

Under en bedre islandsk middag med hajkød, hvalbøffer og lokal akvavit oppe i Isafjördur i det nordvestlig Island betror fiskeren Jon mig, at han vil kunne acceptere Islands EU-medlemskab på den betingelse, at EU lover at blande sig uden om Islands forhold - og så skal Island nok til gengæld blande sig uden om EU's anliggender!

Uanset hvor mange skåltaler, der bliver holdt om, at suveræniteten i klassisk forstand er en død sild, så hæger og våger islændingene over deres selvstændighed.
Nogle iagttagere af Islands europapolitik har peget på, at Socialdemokratiet var en drivende kraft forud for landets tilslutning til EØSsamarbejdet i 1994. Her stod partiet - ganske som i dag - alene i kampen for at integrere Island i Europa.

For at trumfe sin europapolitik igennem skiftede partiet dengang sin venstreorienterede regeringspartner ud med det borgerlige Selvstændighedsparti. Men ikke meget tyder på, at partiet vil kunne gentage kunststykket her i begyndelsen af 10'erne - al den stund, at Selvstændighedspartiet i dag overvejende er kritisk indstillet til et eventuelt EUmedlemskab.

Flere islændinge betror mig, at Island ikke har tilkæmpet sig uafhængighed i 1944 for i 2012 at overgive den til EU. Den stolte Bjartur fra Haldor Laxness Frie Mand er i højeste grad en levende realitet for unge såvel som ældre islændinge - selv om man ofte glemmer den tragiske ende: Bjartur tabte alt ... sin kone, sine børn, sine får!

Alt han elskede tabte han. Men tankegangen er: Hellere fattig og rank end rig og slavebunden...

Erik Boel er landsformand for Europabevegelsen. Tidligere forstander på Krogerup Højskole og Europahøjskolen, chefrådgiver i DIIS og international sekreter $i$ Socialdemokratiet. 